\title{
PERSEPSI PENERAPAN MODEL STEM (SCIENCE, TECHNOLOGY, ENGINEERING AND MATHEMATICS) UNTUK MENINGKATKAN PEMAHAMAN GURU DALAM MENGHADAPI REVOLUSI INDUSTRI 4.0
}

\author{
Mia Nurkanti ${ }^{1}$, Darta $^{2}$ \\ ${ }^{1,2}$ Universitas Pasundan
}

mia.nurkanti@unpas.ac.id,darta@unpas.ac.id

\begin{abstract}
Abstrak
Telah dilakukan pengabdian pada masyarakat tentang pembimbingan guru SD melaksanakan program Bandung Green school sebagai upaya penghijauan sekolah yang ada di Kota Bandung. Tujuan dari PKM ini yaitu ingin bekerjasama dengan para guru Sekolah Dasar yang berada di tengah kota dalam membangun green school melalui pembelajaran STEM (Science, Technology, Engineering and Mathematics). Masalah yang dihadapi oleh para guru adalah belum mempunyai pengetahuan mengelola lingkungan yang sehat, bersih dan nyaman sedangkan program walikota saat itu menginginkan setiap sekolah yang ada di Kota Bandung menyelengarakan Bandung Green school. Tujuan penelitian adalah apakah model pembelajaran STEM (Science, Technology, Engineering and Mathematics) dapat membuat guru memahami cara mengelola lingkungan sekolah. Pengambilan sampel penelitian dilakukan di SD Cihampelas 3 dan 5. Guru yang terlibat sebanyak 43 orang sedangkan yang menjadi subjek penelitian hanya guru yang mengajar di kelas 4 dan 5 yaitu 16 orang. Metode penelitian menerapkan metode peneltian kuantitatif dengan pengambilan data dilakukan melalui metode survey dengan instrumen kuesioner. Hasil penelitian menunjukan bahwa penerapan pembelajaran model STEM dapat memberikan kontribusi signifikan terhadap kemampuan guru dalam mengelola lingkungan sekolah. STEM merupakan salah satu model pembelajaran yang efektif dapat digunakan oleh guru untuk lebih memahami tata cara mengelola lingkungan sekolah
\end{abstract}

Kata Kunci : Bandung Green school, Revolusi Industri 4.0, Pembelajaran STEM, Guru Sekolah Dasar

\section{PENDAHULUAN}

Kerusakan lingkungan yang terjadi secara luas dan terus menerus membuat ancaman bagi kelestarian lingkungan hidup. Sampah dan banjir merupakan contoh kecil dari kerusakan lingkungan yang telah terjadi secara massive di masyarakat indonesia, belum lagi kerusakan yang berdampak luas akan punahnya beberapa spesies tumbuhan dan hewan di pulau kalimantan yang diakibatkan oleh kebakaran hutan dan penebangan pohon secara liar juga tak dapat dihentikan. Ancaman kerusakan lingkungan tersebut menjadi tanggung jawab bersama yang harus dilakukan secara sistematis yang di mulai dari anak usia dini. Pendidikan lingkungan hidup hendaknya diberikan secara simultan kepada anak-anak baik di lingkungan keluarga maupun di lingkungan sekolah.

Pendidikan lingkungan hidup merupakan usaha yang dilakukan secara terus menerus demi melestarikan lingkungan hidup yang dilakukan dari setiap generasi. Secara ekplisit pendidikan lingkungan hidup merupakan usaha manusia untuk menjaga lingkungan hiduo dari ancaman kerusakan hingga kepunahan dan tetap terjaganya daya dukung lingkungan sehingga dapat bertahan lebih 
lama sebagai lingkungan yang lestari (Sumarni, 2008).

Sekolah merupakan tempat yang strategis bagi penanaman pemahaman lingkungan hidup sebagai pondasi yang diharapkan mampu menjembatani dan mendidik anak agar dapat bersikap tanggung jawab dan bijaksana dalam berprilaku terhadap lingkungan.

Green school merupakan salah satu alternatif yang dapat dilakukan dalam memberikan pemahaman terhadap anak untuk lebih mencintai lingkungannya. Green school diharapkan mampu mengurangi masalah lingkungan dan meningkatnya kesejahteraan sekolah (Kobet, 2009) dalam (Iwan \& Rao, 2017). Bangunan green school dirancang untuk menyediakan lingkungan yang sehat sehingga kriteria arsitekturnya pun dirancang untuk meningkatkan efektifitas pencahayaan siang hari dan kualitas udara di dalam ruangan.

Selain prasarana yang dibangun untuk membangun sekolah berbasis lingkungan atau green school, hal lain yang menjadi fokus utama yaitu pendidikan atau pengajaran yang dapat memberikan pemahaman secara menyeluruh terkait dengan perilaku peduli lingkungan. Pelaksanaan pendidikan yang digagas oleh pemerintah yang terdiri dari 18 karakter salah satunya adalah sikap dan perilaku peduli lingkungan yang merupakan sikap dan tindakan yang selalu berupaya mencegah kerusakan pada lingkungan alam dan di sekitarnya, dan mengembangkan upaya-upaya untuk memperbaiki kerusakan alam yang sudah terjadi. Salah satu implementasi dari upaya perilaku peduli lingkungan adalah melalui pendidikan lingkungan hidup. Pendidikan lingkungan hidup adalah suatu proses untuk mengenali nilai-nilai dan menjelaskan konsep dalam rangka mengembangkan keterampilan, sikap yang diperlukan untuk memahami serta menghargai hubungan timbal balik antara manusia, budaya dan lingkungan biofisiknya.

Pendidikan lingkungan hidup yang diberikan kepada siswa dapat dilakukan dengan berbagai macam model pengembangan pembelajaran, salah satunya adalah adalah model pembelajaran STEM (Science, Technology, Engineering and Mathematics). National Research Council (1996) dalam (Idin, 2011) STEM adalah pendekatan pendidikan dan pengajaran yang mengintegrasikan konten dan keterampilan sains, teknologi, teknik dan matematika. STEM bertujuan untuk merancang peningkatan kemampuan masyarakat dalam ilmu pengetahuan dan berinovasi pada produk teknologi sehingga dapat bersaing secara global (Utami, Septiyanto, Wibowo, \& Suryana, 2017).

Pemberian materi pendidikan lingkungan hidup yang disesuaikan dengan model pembelajaran STEM memiliki potensi besar dalam memberikan pemahaman secara aplikatif kepada siswa dan menjadi pondasi pembelajaran dalam mendukung pendidikan revolusi industri 4.0 karena pembelajaran STEM menurut (Kelley, 2016) dalam (Utami et al., 2017) harus mencakup integrasi teknologi dan teknik menjadi ilmu pengetahuan dan matematika, b) mengedepankan penyelidikan ilmiah dan desain teknik, termasuk matematika dan instruksi sains, c) pendekatan kolaboratif terhadap belajar, menghubungkan siswa dan pendidik dengan STEM, d) menyediakan sudut pandang global dan multi perspektif, e) menggabungkan strategi seperti pembelajaran berbasis proyek, menyediakan pengalaman belajar formal dan informal, dan f) memasukan teknologi yang sesuai untuk meningkatkan pembelajaran.

Di dalam pembelajaran model STEM guru bersifat sebagai fasilitator dalam pemecahan masalah dunia nyata dan memeberikan instruksi bagi keterampilan yang harus dimiliki oleh semua siswa di masa mendatang (Margot \& Kettler, 2019). Hal tersebut akan sangat bermanfaat bagi siswa dalam menghadapi tantangan permasalahan lingkungan hidup yang saat iini sedang terjadi dan akan berdampak lebih luas di masa mendatang. Penerapan model pembelajaran STEM yang dibuat dalam menghadapi masa revolusi industri 4.0 yang sangat erat dengan literasi digital menjadi tantangan besar bagi guru untuk mengaplikasikan green school yang bukan hanya ramah terhadap lingkungan sekolah tersebut tetapi juga menjadi pondasi sebagai daya dukung terciptanya green school berbasis teknologi. Hasil akhir dari pembelajaran lingkungan hidup dengan menggunakan model STEM adalah dapat terciptanya sumber daya manusia (SDM) yang selain dapat mengatasi masalah lingkungan hidup namun juga dapat mengaplikasikan penegtahuannya ke dalam sebuah teknologi yang

$$
\text { Pendidikan }
$$

864 
dapat mengurangi kerusakan lingkungan hidup sebagaimana didukung oleh kemajuan pendidikan sebagai tuntutan revolusi industri 4.0.

\section{METODE}

Kerusakan lingkungan yang terjadi secara luas dan terus menerus membuat ancaman bagi kelestarian lingkungan hidup. Sampah dan banjir merupakan contoh kecil dari kerusakan lingkungan yang telah terjadi secara massive di masyarakat indonesia, belum lagi kerusakan yang berdampak luas akan punahnya beberapa spesies tumbuhan dan hewan di pulau kalimantan yang diakibatkan oleh kebakaran hutan dan penebangan pohon secara liar juga tak dapat dihentikan. Ancaman kerusakan lingkungan tersebut menjadi tanggung jawab bersama yang harus dilakukan secara sistematis yang di mulai dari anak usia dini. Pendidikan lingkungan hidup hendaknya diberikan secara simultan kepada anak-anak baik di lingkungan keluarga maupun di lingkungan sekolah.

Pendidikan lingkungan hidup merupakan usaha yang dilakukan secara terus menerus demi melestarikan lingkungan hidup yang dilakukan dari setiap generasi. Secara ekplisit pendidikan lingkungan hidup merupakan usaha manusia untuk menjaga lingkungan hiduo dari ancaman kerusakan hingga kepunahan dan tetap terjaganya daya dukung lingkungan sehingga dapat bertahan lebih lama sebagai lingkungan yang lestari (Sumarni, 2008).

Sekolah merupakan tempat yang strategis bagi penanaman pemahaman lingkungan hidup sebagai pondasi yang diharapkan mampu menjembatani dan mendidik anak agar dapat bersikap tanggung jawab dan bijaksana dalam berprilaku terhadap lingkungan.

Green school merupakan salah satu alternatif yang dapat dilakukan dalam memberikan pemahaman terhadap anak untuk lebih mencintai lingkungannya. Green school diharapkan mampu mengurangi masalah lingkungan dan meningkatnya kesejahteraan sekolah (Kobet, 2009) dalam (Iwan \& Rao, 2017). Bangunan green school dirancang untuk menyediakan lingkungan yang sehat sehingga kriteria arsitekturnya pun dirancang untuk meningkatkan efektifitas pencahayaan siang hari dan kualitas udara di dalam ruangan.

Selain prasarana yang dibangun untuk membangun sekolah berbasis lingkungan atau green school, hal lain yang menjadi fokus utama yaitu pendidikan atau pengajaran yang dapat memberikan pemahaman secara menyeluruh terkait dengan perilaku peduli lingkungan. Pelaksanaan pendidikan yang digagas oleh pemerintah yang terdiri dari 18 karakter salah satunya adalah sikap dan perilaku peduli lingkungan yang merupakan sikap dan tindakan yang selalu berupaya mencegah kerusakan pada lingkungan alam dan di sekitarnya, dan mengembangkan upaya-upaya untuk memperbaiki kerusakan alam yang sudah terjadi. Salah satu implementasi dari upaya perilaku peduli lingkungan adalah melalui pendidikan lingkungan hidup. Pendidikan lingkungan hidup adalah suatu proses untuk mengenali nilai-nilai dan menjelaskan konsep dalam rangka mengembangkan keterampilan, sikap yang diperlukan untuk memahami serta menghargai hubungan timbal balik antara manusia, budaya dan lingkungan biofisiknya.

Pendidikan lingkungan hidup yang diberikan kepada siswa dapat dilakukan dengan berbagai macam model pengembangan pembelajaran, salah satunya adalah adalah model pembelajaran STEM (Science, Technology, Engineering and Mathematics). National Research Council (1996) dalam (Idin, 2011) STEM adalah pendekatan pendidikan dan pengajaran yang mengintegrasikan konten dan keterampilan sains, teknologi, teknik dan matematika. STEM bertujuan untuk merancang peningkatan kemampuan masyarakat dalam ilmu pengetahuan dan berinovasi pada produk teknologi sehingga dapat bersaing secara global (Utami et al., 2017).

Pemberian materi pendidikan lingkungan hidup yang disesuaikan dengan model pembelajaran STEM memiliki potensi besar dalam memberikan pemahaman secara aplikatif kepada siswa dan menjadi pondasi pembelajaran dalam mendukung pendidikan revolusi industri 4.0 karena pembelajaran STEM menurut (Kelley, 2016) dalam (Utami et al., 2017) harus mencakup integrasi teknologi dan teknik menjadi ilmu pengetahuan dan matematika, b) mengedepankan penyelidikan ilmiah dan desain teknik, termasuk matematika dan instruksi sains, c) pendekatan kolaboratif terhadap belajar, menghubungkan siswa dan pendidik dengan STEM, d) menyediakan sudut pandang global dan multi perspektif, e) menggabungkan strategi seperti pembelajaran berbasis proyek,

$$
\text { Pendidikan }
$$


menyediakan pengalaman belajar formal dan informal, dan f) memasukan teknologi yang sesuai untuk meningkatkan pembelajaran.

Di dalam pembelajaran model STEM guru bersifat sebagai fasilitator dalam pemecahan masalah dunia nyata dan memeberikan instruksi bagi keterampilan yang harus dimiliki oleh semua siswa di masa mendatang (Margot \& Kettler, 2019). Hal tersebut akan sangat bermanfaat bagi siswa dalam menghadapi tantangan permasalahan lingkungan hidup yang saat iini sedang terjadi dan akan berdampak lebih luas di masa mendatang. Penerapan model pembelajaran STEM yang dibuat dalam menghadapi masa revolusi industri 4.0 yang sangat erat dengan literasi digital menjadi tantangan besar bagi guru untuk mengaplikasikan green school yang bukan hanya ramah terhadap lingkungan sekolah tersebut tetapi juga menjadi pondasi sebagai daya dukung terciptanya green school berbasis teknologi. Hasil akhir dari pembelajaran lingkungan hidup dengan menggunakan model STEM adalah dapat terciptanya sumber daya manusia (SDM) yang selain dapat mengatasi masalah lingkungan hidup namun juga dapat mengaplikasikan penegtahuannya ke dalam sebuah teknologi yang dapat mengurangi kerusakan lingkungan hidup sebagaimana didukung oleh kemajuan pendidikan sebagai tuntutan revolusi industri 4.0.

\section{HASIL DAN PEMBAHASAN}

\section{Hasil}

Hasil penelitian persepsi guru terhadap penerapan model pembelajaran STEM untuk lebih memberikan pemahaman terhadap siswa dalam pembelajaran lingkungan hidup ditunjukan dengan beberapa jawaban guru yang muncul yang terdiri dari tujuh aspek pertanyaan yang terdiri dari, 1) Infrastrukutr sekolah, 2) kebiasaan siswa, 3) kepedulian siswa, 4) kepedulian guru, 5) kesehatan, 6) kurikulum, dan 7) pengembangan profesional. Ketujuh tema pertanyaan tersebut hasilnya akan dikelompokan berdasarkan jawaban yang diterima dari keenam belas guru sampel penelitian untuk dikelompokan menjadi coding kecenderungan persepsi guru.

Kategori koding guru diadaptasi dari (Kerlin, Santos, \& Bennett, 2015) yang menjelaskan tujuh kategori yang muncul. Setiap kode diberikan skor antara $-1,0$, dan 1 . Jawaban yang muncul dari guru tersebut kemudian dijumlahkan dan di kategorikan berdasarkan kategori koding. Koding tersebut diterjemahkan berdasarkan indikator dari setiap kategori koding yang telah ditentukan, sehingga diketahui nilai persentase dari setip terjemahan koding sesuai jawaban yang dilontarkan oleh guru-guru tersebut yang megajar pada tingkatan sekolah dasar kelas empat dan kelas lima.. Berikut merupakan diagram koding:

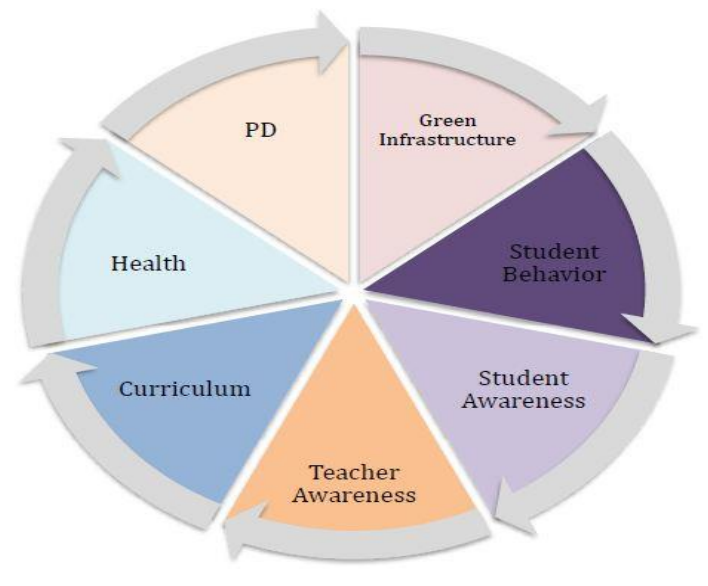

Gambar 1. (Tujuh Kategori Koding) (Kerlin et al., 2015)

Dalam merangsang ketujuh framework tersebut, guru diberikan pertanyaan rangsangan yang mengarah pada indikator ketujuh framework tersebut. Hasil jawaban pertanyaan tersebut kemudian dipilih berdasarkan koding framework yang telah dipersentasikan yang merupakan ajwaban dari ke-16 guru yang menjadi sampel penelitian yaitu guru di Sekolah Dasar Cihampelas 3 dan 5 Kota Bandung Jawa Barat.

\section{Pembahasan}

Hasil penelitian menunjukan bahwa guru telah memahami hal-hal yang dapat mendukung pembelajaran STEM dalam membangun pemahaman daya dukung green school sebagai tuntutan revolusi industri 4.0. Pembelajaran STEM di dalam framework tersebut terdapat pada kategori kurikulum, guru memberikan jawaban model pembelajaran STEM sebagai model pembelajaran 
yang cocok untuk mengaplikasikan green school di sekolah dasar.

Berikut merupakan hasil persentase jawaban guru yang disesuaikan dengan indikator ketujuh framework green school sekolah dasar. Jawaban guru bersifat tidak terstuktur sehingga peneliti harus melakukan pengelompokan jawaban sesuai dengan indikator indikator yang terdapat pada (tabel 1) di atas.

\section{Persepsi Guru Terhadap Daya Dukung Pembelajaran} STEM Dalam Penciptaan Green School

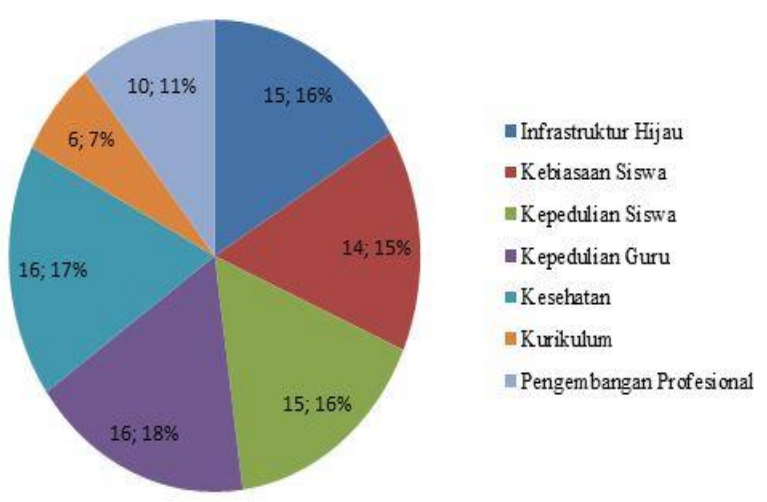

Gambar 2. (Persentase Jawaban Guru dalam Mendukung Green school di Sekolah Dasar)

Dari ketujuh koding yang diadaptasi dari framework (Kerlin et al., 2015) diketahui persepsi guru terhadap daya dukung pembelajaran yang dapat membantu pembangunan green school pada tingkat sekolah dasar telah membaik. Alasan utama guru dalam mendukung pembangunan dan pemahaman green school pada siswa sekolah dasar yang paling utama adalah kesehatan. Pemberian materi lingkungan hidup sebenarnya bertujuan untuk pemberian materi kesehatan yang penting diketahui oleh siswa sejak kecil, karena pendidikan kesehatan yan dikutip dari (Erwin Setyo, 2012) dalam (Sari \& Prasetyawati, 2013) merupakan proses membantuk seseorang yang dapat bertindak sendiri ataupun kolektif yang dapat membuat keputusan berdasarkan pengetahuannya mengenai hal yang dapat mempengaruhi kesehatan pribadinya dan orang lain untuk meningkatkan kemampuan masyarakat dalam memelihara kesehatannya dan tidak hanya mengaitkan diri pada peningkatan pengetahuan, sikap dan praktik saja tetapi dapat memperbaiki lingkungan (Sari \& Prasetyawati,
2013). Kesehatan merupakan pondasi terpenting yang diutarakan guru mengenai alasan terciptanya green school karena akan berdampak pada tingkat kehadiran siswa di sekolah setiap harinya. Hal lain yang menarik dari persepsi guru yaitu sedikitnya guru membahas kurikulum dalam pembangunan green school, padahal kurikulum merupakan instruksi tertinggi dalam pemberian materi pembelajaran berbasis lingkungan.

Program peninjauan dan penerapan kurikulum berlandaskan semangat cinta lingkungan dapat mengintegrasikan materi lingkungan hidup dalam beberapa mata pelajaran secara terintegrasi. Pembentukan karakter dan perubahan perilaku siswa dilakukan dengan menekankan siswa untuk selalu menerapkan kegiatan cinta lingkungan secara disiplin, konsisten dan berkelanjutan (Paramita \& Indiyati, 2017). pengembangan profesional dalam mendukung green school pada sekolah dasar diperlukan karena dengan adanya hal tersebut guru dapat bersikap inovatif saat pemberian praktik pengenalan green school kepada siswa. Pengembangan profesional guru pada dasarnya merupakan kegiatan reflektif dari pengalaman belajar yang seringkali guru dapatkan di dalam kelas sehingga guru dapat memberikan kesan berbeda di setiap pembelajaran dan praktik di lapangan (Girvan, Conneely, \& Tangney, 2016).

Kepedulian guru dalam memberikan materi lingkungan hidup dengan menggunakan model STEM berperan penting karena guru bertanggung jawab dalam mentransmisikan pengetahuan dan menciptakan kesadaran tentang lingkungan kepada siswa dengan harapan agar siswa siap untuk membantu melanjutkan peran dalam melestarikan lingkungan yang bersih dan sehat. Selain itu kepedulian guru juga sangat penting karena guru khusunya bagi siswa kelas empat dan lima sekolah dasar bertanggung jawab menjadi panutan bagi siswanya dalam memecahkan masalah lingkungan baik lokal maupun global. Sehingga kepedulian guru adalah visi yang harus disiapkan untuk menjadi misi guru dalam melatih konsep dan keterampilannya kepada siswa (Amnah \& Rauf, 2015).

Pada akhir model pembelajaran STEM dipilih karena memiliki banyak keuntungan alternatif yang dapat mendukung pemahaman green school di sekolah dasar karena model pembelajaran 
STEM dapat menciptakan peluang untuk mengintegrasikan sains dan literasi lingkungan ke dalam pembelajaran sehari-hari. STEM juga merupakan serangkaian kerangka kerja yang ditingkatkan melalui dua fokus yaitu pendidikan lingkungan dengan literasi digital dan literasi informasi yang terdapat pada kajian revolusi industri 4.0 yang saling mendukung dalam proses pembangunan green school di sekolah dasar (Cole, 2019).

\section{KESIMPULAN}

Kegiatan pengabdian kepada masyarakat ini berlangsung dalam waktu yang cukup lama, mulai dari observasi lokasi sekolah, observasi kegiatan pemberian materi lignkungan hidup, memeriksa rancangan rencana pelaksanaan pembelajaran hingga melakukan wawancara tidak terstruktur kepada guru sebagai partisipan penelitian.

Pemberian pemahaman model STEM

(Science, Technology, Engineering and Mathematics) sebagai model pembelajaran dalam pemberian materi lingkungan hidup sebagai daya dukung pembangunan green school di sekolah dasar cukup baik terlebih guru telah memiliki dasar pemahaman bahwa pendidikan lingkungan hidup harus bersifat aplikatif sehingga siswa dapat membantu guru dalam membangun green school di sekolah tersebut. Bantuan informasi digital juga membantu dan mempermudah guru dalam memberikan materi aplikatif kepada siswa.

\section{REFERENSI}

Amnah, R., \& Rauf, A. (2015). Improving Attitude Towards Green Slgea-Code Module. International Journal of Technical Research and Applications, 35(35), 26-31.

Cole, L. B. (2019). Green Building Literacy: A Framework For Advancing Green Building Education. International Journal of STEM Education, 6(18), 1-13.

Girvan, C., Conneely, C., \& Tangney, B. (2016). Extending Experiential Learning In Teacher Professional Development. Teaching and Teacher Education, 58, 129-139. https://doi.org/10.1016/j.tate.2016.04.009

Idin, S. (2011). An Overview of STEM Education and Industry 4.0.

Iwan, A., \& Rao, N. (2017). The Green school
Concept: Perspectives of Stakeholders from Award-Winning Green Preschools in Bali, Berkeley, and Hong Kong. Journal of Sustainability Education, 16, 1-23.

Kerlin, S., Santos, R., \& Bennett, W. (2015). Green schools as Learning Laboratories? Teachers' Perceptions of Their First Year in a New Green Middle School. Journal of Sustainability Education, 8(January), 1-18.

Margot, K. C., \& Kettler, T. (2019). Teachers ' Perception Of STEM Integration And Education: A Systematic Literature Review. International Journal of STEM Education, 6(2), 1-16.

Paramita, V. S., \& Indiyati, D. (2017). Manajemen Sekolah Hijau Berwawasan Lingkungan. Jurnal Dharma Bhakti Ekuitas, 02(01), 159166.

Sari, T. P., \& Prasetyawati, I. (2013). Pendidikan Kesehatan Sekolah Sebagai Proses Perubahan Perilaku Siswa. Jurnal Pendidikan Jasmani Indonesia, 9(2), 141-147.

Sumarni. (2008). Sekolah Hijau Sebagai Alternatif Pendidikan Lingkungan Hidup Dengan Menggunakan Pendekatan Kontekstual. Jurnal Ilmu Pendidikan, 15(1), 19-25.

Utami, I. S., Septiyanto, R. F., Wibowo, F. C., \& Suryana, A. (2017). Pengembangan STEM-A (Science, Technology, Engineering, Mathematic And Animation) Berbasis Kearifan Lokal Dalam Pembelajaran Fisika. Jurnal Ilmiah Pendidikan Fisika Al-Biruni, 06(1), 67-73. https://doi.org/10.24042/jipf 